\title{
Food resource utilisation by the Magellanic penguin evaluated through stable-isotope analysis: segregation by sex and age and influence on offspring quality
}

\author{
Manuela G. Forero ${ }^{1, *}$, Keith A. Hobson ${ }^{2,3}$, Gary R. Bortolotti ${ }^{2}$, Jose A. Donázar ${ }^{4}$, \\ M. Bertellotti ${ }^{4}$, G. Blanco ${ }^{5}$ \\ ${ }^{1}$ Instituto Mediterráneo da Estudios Avanzadas (C.S.I.C.-U.I.B), C/Miguel Marqués, 21, 07190 Esporles, Mallorca, Spain \\ ${ }^{2}$ Department of Biology, University of Saskatchewan, Saskatoon, Saskatchewan S7N5E2, Canada \\ ${ }^{3}$ Canadian Wildlife Service, 115 Perimeter Road, Saskatoon, Saskatchewan S7N0X4, Canada \\ ${ }^{4}$ Department of Applied Biology, Estación Biológica de Doñana, Consejo Superior de Investigaciones Científicas, \\ Apdo. 1056, 41013 Sevilla, Spain \\ ${ }^{5}$ Instituto de Investigación en Recursas Cinegéticos (C.S.I.C.-U.C.L.M.), Ronda de Toledo, s/n, 13005 Civdad Real, Spain
}

\begin{abstract}
We used stable-isotope analysis (SIA) to evaluate sources of variation in the diet of and prey selection by Magellanic penguins Spheniscus magellanicus breeding on the Argentinean Patagonia coast. Our aim was to determine potential sources of variation in diet, focusing mainly on sex and age, although geographic and temporal effects were also taken into account. In addition, we evaluated how prey selection affects offspring quality. We measured stable nitrogen $\left(\delta^{15} \mathrm{~N}\right)$ and carbon $\left(\delta^{13} \mathrm{C}\right)$ isotope values in whole blood of chicks $(n=98)$, yearlings $(n=15)$ and adults $(n=143)$ in 9 different breeding colonies during 2 consecutive breeding seasons (1999 and 2000). We also measured stable isotope values in representative prey consumed by this species. Stable nitrogen and carbon isotope values in blood for penguins varied from 17.8 to $20.0 \%$ and from -18.1 to $-14.8 \%$, respectively. Both colony and season had a significant effect on the 2 isotope signatures. Adult males had higher blood $\delta^{15} \mathrm{~N}$ and $\delta^{13} \mathrm{C}$ values than females. Age significantly affected both $\delta^{15} \mathrm{~N}$ and $\delta^{13} \mathrm{C}$ values, with chicks showing the highest and yearlings the lowest $\delta^{15} \mathrm{~N}$ values. Chicks showed lower $\delta^{13} \mathrm{C}$ values than yearlings and adults. Mean prey $\delta^{15} \mathrm{~N}$ values ranged from $13.6 \%$ in squid to $18.0 \%$ in octopus. As anchovy, the main prey consumed by the species in the study area, did not differ from other fish species (hake) in its $\delta^{15} \mathrm{~N}$ value, we used it to represent a fish dietary alternative. Using a 2-source (anchovy and squid) isotopic mixing model, we determined that the mean proportion of anchovy in the diet was $49 \%$ for yearlings, $76 \%$ for chicks, and $69 \%$ and $67 \%$ for adult males and females, respectively. Sex and age differences in diet, as revealed by stable isotopes, may be the consequence of individual morphology (sexual size dimorphism) and reproductive constraints imposed by chick development since growing young require more nutritive prey than adults and yearlings. This reasoning would also explain the significant and positive correlation found between proportion of anchovy in the diet and body condition of chicks.
\end{abstract}

KEY WORDS: Diet segregation · Stable-isotope analysis · Magellanic penguin · Argentinean Patagonia · Chick quality

Resale or republication not permitted without written consent of the publisher

\section{INTRODUCTION}

Seabirds are important components of marine ecosystems and occupy a range of trophic levels in marine food webs (Croxall 1987, Hobson \& Welch 1992).
Seabirds may thus be good indicators of environmental changes (Ainley 1980, Jarman et al. 1996), including fluctuations in prey abundance and distribution (Hatch \& Sanger 1992, Montevecchi 1993, Montevecchi \& Myers 1995). In addition, seabirds are generally be- 
lieved to be regulated by their food supply, which is thought to be sparse and patchily distributed (Anderson et al. 1982, Monaghan et al. 1989, Cairns 1992). There is an increasing interest in the study of diet composition and feeding ecology of seabirds as an important key to understanding the dynamics of their populations and as indicators of environmental health (Montevecchi 1993).

Factors influencing feeding behavior and prey choice by individuals range from behavioral to morphological characteristics, and all of them may impact fitness of individuals (Pierotti \& Annet 1995). Within populations, age and experience of individuals are factors contributing to variation in exploitation of food resources, but few studies have investigated differences in diet between different age-classes in seabirds (see however Hobson 1993, Pedrocchi et al. 1996, Bearhop et al. 2000, Hodum \& Hobson 2000). Nonetheless, differences in competitive ability caused by factors such as age or experience may largely determine quality and quantity of food resources exploited by individuals. A second potential source of variation in feeding behavior within populations is differences in morphology. Many studies have reported differences in the diets of males and females of seabirds (e.g. Koffijberg \& van Eerden 1995, Kato et al. 1996, Clarke et al. 1998, González-Solís et al. 2000). The 'Intersexual Competition Hypothesis' predicts that in dimorphic species, reduction of competition for food between the sexes results from the capture of different prey types by each sex and that this is one of the main selective forces maintaining sexual dimorphism (Selander 1972). Important differences in exploitation of food resources with stage of the life cycle of individuals may be yet another factor contributing to variation in diets within species (Pierotti \& Annet 1991, Bertellotti \& Yorio 1999, Velando \& Freire 1999). The optimal foraging theory (Emlen 1966, McArthur \& Pianka 1966, Stephens and Krebs 1986) was built on the assumption that animals would enhance their fitness by foraging in ways that maximize the net rate of energy gain. Under this theoretical framework we could predict how parents, during the breeding season, should distribute food resources between themselves and their offspring. In this context, we hypothesize that parents may optimize their success and their investment in offspring by provisioning themselves with different prey than they feed their chicks, as energetic needs of chicks during growing should be higher than in adults (Moreno \& Sanz 1996). Finally, as most seabird species are colonial, variation in the distribution of marine resources could introduce important differences in the diet among geographical locations (Croxall \& Lishman 1987, Frere et al. 1996, Bertellotti \& Yorio 1999, Velando \& Freire 1999).
Despite the importance of identifying sources of variation in diet and foraging behavior in order to understand the ecology of seabirds, these aspects have not been well studied. This gap is due, in part, to methodological limitations. Most studies of seabird diet have relied upon examination of stomach contents of adult birds. These conventional methods are useful for identifying specific prey taxa. However, several sources of bias exist with this procedure, including the rapid digestion of soft-bodied prey (see reviews in Duffy \& Jackson 1986 and González-Solís et al. 1999). Recently, numerous studies have used alternative approaches to dietary analyses by measuring the proportional abundance of stable isotopes of various elements in different tissues from both consumer and prey species (e.g. Hobson 1993, Hobson et al. 1994, Sydeman et al. 1997, Thomson et al. 1999). This approach is based on the fact that stable-isotope ratios of nitrogen $\left({ }^{15} \mathrm{~N}:{ }^{14} \mathrm{~N}\right.$, expressed as $\left.\delta^{15} \mathrm{~N}\right)$ and carbon $\left({ }^{13} \mathrm{C}:{ }^{12} \mathrm{C}\right.$, expressed as $\left.\delta^{13} \mathrm{C}\right)$ in the consumer tissues reflect those in their prey in a predictable manner (DeNiro \& Epstein 1978, 1981). In marine ecosystems a step-wise enrichment of ${ }^{15} \mathrm{~N}$ typically occurs with each trophic level (Hobson \& Welch 1992, Hobson et al. 1994, Sydeman et al. 1997) and ranges between about 3 and 5\% (Michener \& Schell 1994). $\delta^{13} \mathrm{C}$ values provide less information on trophic level but can reveal sources of feeding, including inshore versus offshore foraging in marine habitats, as phytoplankton has lighter $\delta^{13} \mathrm{C}$ than many inshore plants (Hobson et al. 1994, France 1995, Hobson et al. 1995). Thus, $\delta^{13} \mathrm{C}$ values can be used as an approximate indicator of the zone of feeding around the colony. Recent investigations have also indicated that a great deal of dietary information can be obtained from the isotopic analysis of blood, thereby reducing the need to sacrifice birds just for analysis of diet (Hobson \& Clark 1992, 1993, Ben-David et al. 1997, Hobson et al. 1997, Hodum \& Hobson 2000). In addition, the period over which tissue isotopic concentrations reflect diet depends, in part, on the isotopic turnover rate in that tissue (Tieszen et al. 1983, Hobson 1993). Stableisotope signatures of whole blood represent dietary information integrated over a period of at least $4 \mathrm{wk}$ (Hobson \& Clark 1992). Isotopic analysis of blood samples are appropriate, then, for studying feeding ecology during the chick-rearing period or other discrete periods of time.

In this study, we used stable-isotope analysis (SIA) to test potential sources of variation in the diet of Magellanic penguins Spheniscus magellanicus, a dimorphic seabird breeding on the Argentinean Patagonia coast. We focused primarily on age and sex differences as sources of variation in the diet of this species. We measured variation in stable-nitrogen and carbon isotope ratios for penguins from different colonies and for their 
main prey. In addition, we examined if prey selection differed between individuals of different age and reproductive status and if prey distribution between parents and chicks had consequences for breeding performance of individuals as measured by offspring body condition.

\section{MATERIALS AND METHODS}

Study area and species. This study was conducted in the Chubut province of Argentinean Patagonia during 2 consecutive breeding seasons (1999 and 2000). In this area we selected 9 breeding colonies distributed across a long extension of coast (see Table 1). Magellanic penguins arrive at their breeding colonies in late August and early September (Boersma et al. 1990). During the first $2 \mathrm{wk}$ after arrival, they remain on the beach without consuming food until eggs are laid (Scolaro 1984). The breeding season extends then to late January, when chicks leave the colonies. Clutches typically contain 2 eggs, but second-hatched chicks are lost from a high proportion of nests due mainly to starvation (Boersma \& Stokes 1995). Nest relief periods between members of pairs become shorter from the laying and incubation to the chick stage. Both males and females provide food to chicks (Stokes \& Boersma 1998). During the chick-rearing period food is delivered to chicks once every $24 \mathrm{~h}$ by 1 member of the pair (Scolaro 1984).

The Magellanic penguin is a diving species that forages primarily on pelagic schooling fishes and to a lesser extent on squid. In our study area, the most common prey during the breeding season is anchovy (Engraulis anchoita) while hake (Merluccius hubbsi), squid (Loligo and Illex sp.) and crustaceans (Artemisia longinaris) are secondary prey (Scolaro et al. 1999). Estimations of foraging ranges for the chick-rearing period, based on chick-feeding intervals and mean swimming speeds, are about $30 \mathrm{~km}$ (Scolaro 1984, Wilson et al. 1995).

Sampling penguins and prey. We visited colonies when most of the chicks were about $70 \mathrm{~d}$ old, and in some cases a few days before they left the nest. Most chicks were caught while they were attended by their parents, so we also captured the adult that was present at that time. Yearlings, identified by molt and plumage (Williams 1995), were sampled on the shore. We measured (to the nearest $\mathrm{mm}$ ) bill length and bill depth using calipers, and flipper length using a wing rule. Weighing was carried out using a spring balance with a precision of $25 \mathrm{~g}$. Some structural body measurements of chicks, such as bill length, had not reached asymptotic values at the time of sampling (Boersma et al. 1990). Previous studies have shown that bill length grows linearly with age throughout the chick period (Boersma et al. 1990). Because we sampled chicks differing slightly in age, we controlled for bill length (as an indicator of age) to remove possible age effects when calculating an index of body condition. Because chicks of this species are sexually dimorphic in size (authors' unpubl. data), sex (determined by molecular procedures, see below) was also included in the calculation of body condition. As an index of body condition of the chicks we used the residuals from an ANCOVA with log body mass as the dependent variable, sex as the main factor and log of flipper and bill length as covariates $\left(\mathrm{r}^{2}=0.342, F_{3,304}=51.890, \mathrm{p}<0.001\right)$. An additional number of chicks sampled in the same colonies and period as part of other studies (see Forero et al. 2001, Jovani et al. 2001, Tella et al. 2001) was used to calculate this index.

Before releasing individuals, about $1 \mathrm{ml}$ of blood was extracted from the brachial or tarsal veins. The blood was transferred to 2 different vials containing $1.5 \mathrm{ml}$ of $70 \%$ ethanol (see Hobson et al. 1997). One of the samples of blood was used for stable-isotope analyses and the other one was processed for molecular sexing of the birds. Sexing of birds was carried out using the primers $2945 \mathrm{~F}, \mathrm{cFR}$ and $3224 \mathrm{R}$ as described by Ellegren (1996), which provide a universal method for sexing birds (e.g. M.B. et al. unpubl. data). Final sample sizes by colony, sex and age varied due to the differential difficulty of capturing birds in different colonies and some losses during sample processing.

Based on previous studies of the diet of Magellanic penguins (Scolaro \& Badano 1986, Frere et al. 1996, Gandini et al. 1999, Scolaro et al. 1999), we selected the following prey species for further analyses of stable isotopes: anchovy, hake, Argentine shrimp (Artemisia longinaris), Patagonian and Argentine squids (Loligo and Illex sp., respectively) and Patagonian octopus (Octopus tehuelche). Prey samples were collected from the waters where the penguins forage, inshore and offshore, the latter supplied by the fishing industry. Additionally, we obtained some prey from regurgitates that occurred as we handled the birds. Species determination of prey was performed directly in the field, as most of the prey samples were from whole animals. After that, we preserved a small portion of soft tissue from each prey in $5 \mathrm{ml}$ of $70 \%$ ethanol for use in stableisotope analyses.

Stable-isotope analyses. Samples of prey and blood of penguins were stored at room temperature (20 to $25^{\circ} \mathrm{C}$ ) until isotope analysis. Ethanol was removed from prey samples by successive rinsing in distilled water and freeze-drying. Prey tissues were treated for lipid extraction using a Soxhlet apparatus with chloroform solvent and then dried at $60^{\circ} \mathrm{C}$ for $24 \mathrm{~h}$ to remove any residual solvent. Extraction of lipids was not necessary 
for blood samples because the lipid component in blood is generally very low (Deuel 1955). Whole blood stored in solution was freeze-dried and then powdered. Stable-carbon and nitrogen isotope assays were performed on $1 \mathrm{mg}$ subsamples of homogenized materials by loading into tin cups and combusting at $1800^{\circ} \mathrm{C}$ in a Robo-Prep elemental analyzer. Resultant $\mathrm{CO}_{2}$ and $\mathrm{N}_{2}$ gases were then analyzed using an interfaced Europa 20:20 continuous-flow isotope ratio mass spectrometer (CFIRMS) with every 5 unknowns separated by 2 laboratory standards (egg albumin). Stableisotope abundances were expressed in $\delta$ notation as the deviation from standards in parts per thousand (\%o) according to the following equation:

$$
\delta X=\left[\left(R_{\text {sample }} / R_{\text {standard }}\right)-1\right] \times 1000
$$

where $X={ }^{15} \mathrm{~N}$ or ${ }^{13} \mathrm{C}$, and $R=$ the corresponding ratio ${ }^{15} \mathrm{~N} /{ }^{14} \mathrm{~N}$ or ${ }^{13} \mathrm{C} /{ }^{12} \mathrm{C}$. The $R_{\text {standard }}$ for ${ }^{15} \mathrm{~N}$ is that for atmospheric $\mathrm{N}_{2}$ (air) and for ${ }^{13} \mathrm{C}$ is that for Pee Dee Belemnite (PDB). Based on numerous measurements of organic standards (albumen and collagen) the analytical precision $( \pm 1 \mathrm{SD})$ of these measurements is estimated to be \pm 0.1 and $\pm 0.3 \%$ for carbon and nitrogen, respectively (Hobson et al. 1994).

Isotopic models. We used a 2-source isotopic mixing model based on $\delta^{15} \mathrm{~N}$ values (Hobson 1993, Hodum \& Hobson 2000) to estimate what proportion of the penguin diet was comprised of each of the major diet sources (anchovy or squid). This linear mixing model using 2 endpoints and 1 isotope follows on as a simple case of the linear procedure proposed by Phillips (2001). As both isotopic endpoints did not vary in their carbon and nitrogen concentrations (unpubl. data), it was not necessary to make adjustments based on differential compositions (Phillips \& Koch 2001). Because of the dominance of anchovy in the diet of Magellanic penguins (Scolaro et al. 1999) and its similar isotopic composition to that of other fishes included in the diet (see 'Results'), we used anchovy as the sole representation of fish in the diet. In addition, we also assumed that the isotopic fractionation factor $\left(\Delta_{\mathrm{dt}}\right)$ for $\delta^{15} \mathrm{~N}$ between diet and penguin whole blood was $3 \%$, and that it was not affected by age (DeNiro \& Epstein 1981, Minagawa \& Wada 1984, Hodum \& Hobson 2000). For the simplest situation involving only 2 main dietary options (anchovy and squid) that are segregated trophically (see 'Results'), the relative contribution of each prey type to the diet of a consumer was estimated according to the following relationship:

$$
P_{\mathrm{a}}=\left(D_{\mathrm{t}}-D_{\mathrm{b}}\right) /\left(D_{\mathrm{b}}-D_{\mathrm{a}}\right)
$$

where $P_{\mathrm{a}}$ is the proportion of the diet derived from source 'a'; $D_{\mathrm{t}}$ the $\delta^{15} \mathrm{~N}$ value of the consumer blood; and $D_{\mathrm{a}}$ and $D_{\mathrm{b}}$ are the consumer blood $\delta^{15} \mathrm{~N}$ values corresponding to exclusive diets of type ' $a$ ' and ' $b$ ' (i.e. anchovy and squid) respectively, calculated as the isotopic value of the prey plus the enrichment factor $\left(\Delta_{\mathrm{dt}}\right)$ between the prey and consumer.

Statistical analyses. To account for possible variation in isotopic signatures between colonies and years, we first assessed whether there were colony or year effects on both blood $\delta^{15} \mathrm{~N}$ and $\delta^{13} \mathrm{C}$ values. When these effects were significant for any of the isotope signatures, these factors were taken into account in further analyses to avoid possible biases in the results. Differences between sexes were tested for adults and chicks separately. Age effects were explored in those colonies where we sampled the 3 age classes. Differences in $\delta^{15} \mathrm{~N}$ values among prey types were analyzed by 1 -way ANOVA. When post-hoc comparisons were required, we used the Tukey Honest Significant Difference test (HSD). The effect of $\delta^{15} \mathrm{~N}$ on body condition of chicks was analyzed using linear regression and 1-tailed tests. Because penguin chick traits vary with diet (Heath \& Randall 1985), we predicted that body condition of chicks would improve as the proportion of fish in the diet increased. In some colonies, sample size was too small for some age or sex classes (see Table 1), so some of them were excluded for some analyses. Normality of distributions was assessed through inspection of normal plots and Kolmogorov-Smirnov test and departures from homogeneity of variances using Levene's test.

\section{RESULTS}

A total of 256 penguins from 9 different colonies was sampled for blood stable-isotope signatures (Table 1). Differences in isotope signatures among colonies were analyzed separately by year using those colonies sampled in the same breeding season. We found a significant effect of colony identity on $\delta^{15} \mathrm{~N}$ (1-way ANOVA, 1999: $F_{5,153}=9.89, \mathrm{p}<0.001 ; 2000: F_{5,91}=5.35$, $\mathrm{p}<0.001)$ and $\delta^{13} \mathrm{C}$ values (1999: $F_{5,153}=59.24$, $\left.\mathrm{p}<0.001 ; 2000: F_{5,91}=9.91, \mathrm{p}<0.001\right)$. Annual effects on isotope signatures were explored in the 3 colonies that were sampled during 2 consecutive breeding seasons (see Table 1). There were no differences between years in $\delta^{15} \mathrm{~N}$ values in any colony (2-way ANOVA, year: $F_{1,143}=2.09, \mathrm{p}=0.15$; colony: $F_{2,143}=6.88$, $\mathrm{p}<0.01$; colony $\times$ year: $\left.F_{2,143}=2.29, \mathrm{p}=0.10\right)$; however, for $\delta^{13} \mathrm{C}$ values, year, colony and the interaction were significant (year: $F_{1,143}=52.14, \mathrm{p}<0.01$; colony: $F_{2,143}=74.81, \mathrm{p}<0.001$; colony $\times$ year: $F_{2,143}=8.77$, $\mathrm{p}<0.001$ ), indicating that differences in $\delta^{13} \mathrm{C}$ between years varied among colonies. Previous results also indicated that differences among colonies in both isotopes remained significant by considering only these 3 colonies. Post-hoc tests showed that $\delta^{15} \mathrm{~N}$ values in 


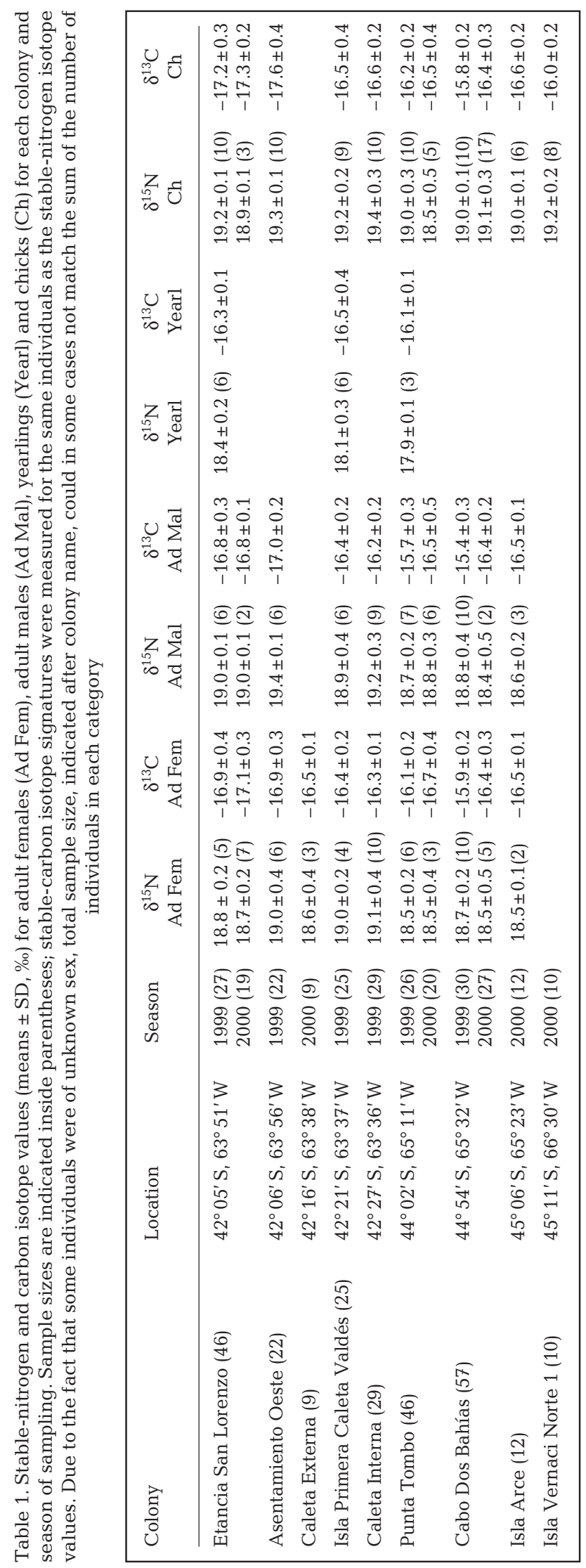

Punta Tombo (see Table 1) were different from the other 2 colonies (Tukey HSD test, all p < 0.001), which showed similar values of this isotope (Tukey HSD test, $\mathrm{p}=0.76)$. For $\delta^{13} \mathrm{C}$ values, there were significant differences among all colonies (Tukey HSD test, all $p<0.007)$. Therefore, the effects of colony on $\delta^{15} \mathrm{~N}$ values, and colony, year and its interaction on $\delta^{13} \mathrm{C}$ values, were taken into account in further analyses by including these terms in the models.

Nitrogen and carbon isotope values in blood for penguins varied from 17.8 to $20.0 \%$ and from -18.1 to $-14.8 \%$, respectively. $\delta^{15} \mathrm{~N}$ and $\delta^{13} \mathrm{C}$ values were not correlated in chicks (Pearson rank correlation, $\mathrm{r}=-0.14$, $\mathrm{p}=0.17$ ) or adults $(\mathrm{r}=0.03, \mathrm{p}=0.17)$, so we analyzed the effects of age and sex separately for each isotope.

Differences between the sexes in $\delta^{15} \mathrm{~N}$ and $\delta^{13} \mathrm{C}$ values were analyzed excluding the colonies Caleta Externa and Isla Vernaci Norte 1 (see Table 1), because we did not know the sex of most of the birds sampled there. For chicks, sex had no influence on blood $\delta^{15} \mathrm{~N}$ (2-way ANOVA, sex: $F_{1,72}=1.48, \mathrm{p}=0.23$; colony: $F_{6,72}=4.61, \mathrm{p}<0.001 ;$ sex $\times$ colony: $F_{6,72}=0.07, \mathrm{p}=$ 0.99 ) or $\delta^{13} \mathrm{C}$ values (3-way ANOVA, sex: $F_{1,75}=0.01$, $\mathrm{p}=0.94$; colony: $F_{6,75}=30.77, \mathrm{p}<0.001$; year: $F_{1,75}=$ $6.79, \mathrm{p}=0.01$; colony $\times$ year: $\left.F_{2,75}=26.07, \mathrm{p}<0.05\right)$. In adults, sex significantly influenced $\delta^{15} \mathrm{~N}$ (sex: $F_{1,101}=$ 4.67, p $=0.03$; colony: $F_{6,101}=9.49, \mathrm{p}<0.001$; $\operatorname{sex} \times$ colony: $F_{6,101}=0.85, \mathrm{p}=0.53$ ) and $\delta^{13} \mathrm{C}$ values (sex: $F_{1,104}=10.1, \mathrm{p}<0.01$; colony: $F_{6,104}=31.04, \mathrm{p}<0.001$; year: $F_{1,104}=46.75, \mathrm{p}<0.001:$ colony $\times$ year: $F_{2,104}=$ $6.92, \mathrm{p}<0.01)$. These results indicated that adult males had higher blood $\delta^{15} \mathrm{~N}$ and $\delta^{13} \mathrm{C}$ values than females (Table 1, Fig. 1). Differences between male and female yearlings could not be explored due to the small samples sizes (see Table 1).

Influence of age on blood isotope values was tested in those colonies where we simultaneously sampled chicks, yearlings and adults (Table 1). Age significantly influenced both $\delta^{15} \mathrm{~N}$ (2-way ANOVA, age: $F_{2,18}=51.93, \mathrm{p}<0.001$; colony: $F_{2,108}=9.20, \mathrm{p}<0.001$; colony $\times$ age: $\left.F_{4,108}=1.8, \mathrm{p}=0.13\right)$ and $\delta^{13} \mathrm{C}$ values (3-way ANOVA, age: $F_{2,110}=9.5, \mathrm{p}<0.001$; colony: $F_{2,110}=38.4, \mathrm{p}<0.001$; year: $F_{1,110}=15.34, \mathrm{p}<0.001$; colony $\times$ year: $\left.F_{1,109}=5.23, \mathrm{p}=0.02\right)$. Values of blood $\delta^{15} \mathrm{~N}$ were different among the 3 age classes (post hoc Tukey HSD test, all p < 0.001). Chicks had the highest, adults intermediate, and yearlings the lowest $\delta^{15} \mathrm{~N}$ values (Table 2, Fig. 1). For $\delta^{13} \mathrm{C}$, chicks had significantly lower values than both adults and yearlings (Tukey HSD test, all $\mathrm{p}<0.04)$. Yearlings and adults showed similar values for $\delta^{13} \mathrm{C}$ (Tukey HSD test, $\mathrm{p}>0.14$ ) (Table 2, Fig. 1).

Mean $\delta^{15} \mathrm{~N}$ values for the main prey species of Magellanic penguin varied from $13.6 \%$ in both squid species to $18.0 \%$ in octopus (Fig. 1). Overall, differences 


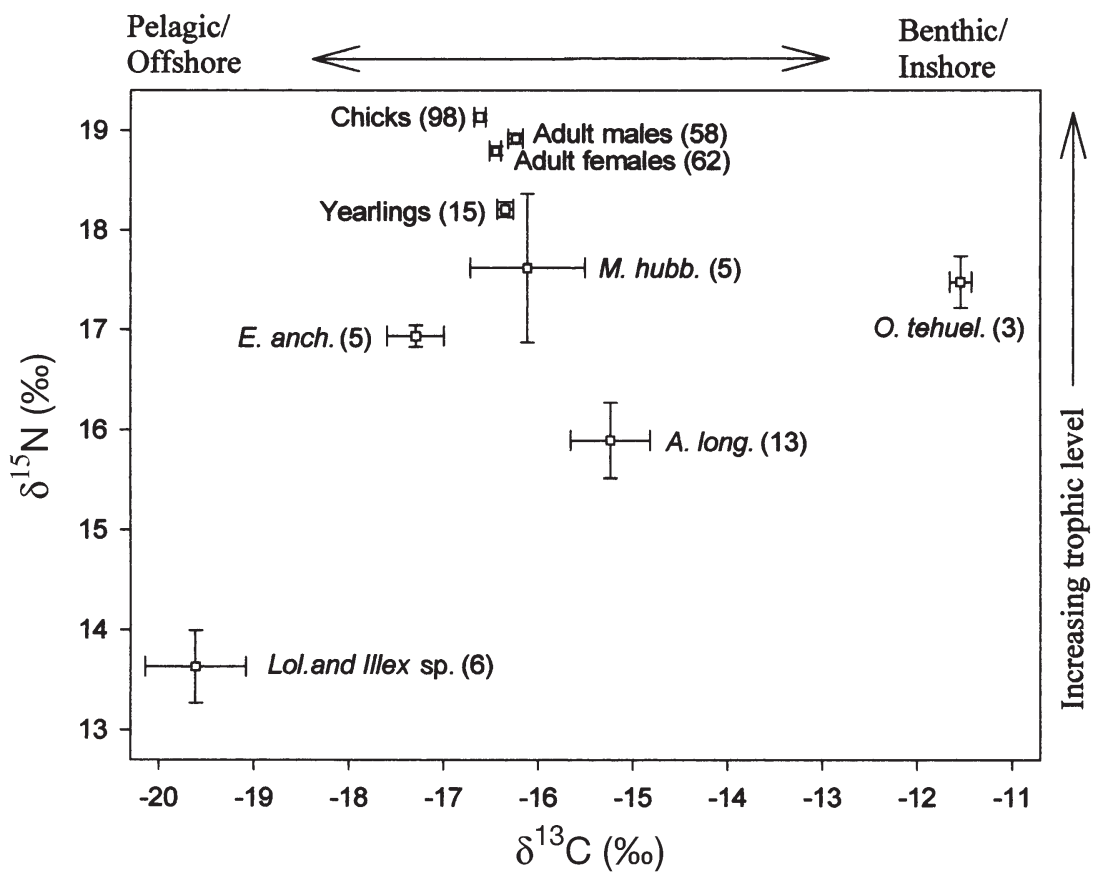

Fig. 1. Stable nitrogen and carbon isotope values (mean $\pm \mathrm{SE}$ ) of penguins and prey species. Prey abreviations: A. long. = Argentine shrimp (Artemisia longinaris); Lol. and Illex sp. = Patagonian and Argentine squid (Loligo and Illex sp.).; E. anch. = anchovy (Engraulis anchoita) $;$. hubb. = hake (Merluccius hubbsi); O. tehuel. $=$ Patagonian octopus (Octopus tehuelche). Sample sizes given in parentheses

among species were significant $\left(F_{5,27}=0.1, \mathrm{p}<0.0001\right)$. Post-hoc tests showed that these differences were due to different $\delta^{15} \mathrm{~N}$ values between squids and the rest of the prey species (Tukey HSD test, all $\mathrm{p}<0.001$ ). The rest of species did not differ in their $\delta^{15} \mathrm{~N}$ values (Tukey HSD test, all $p>0.08$ ), with differences between fish species, hake and anchovy, being far from significant (Tukey HSD test, $\mathrm{p}=0.9$ ). Because anchovy has been previously shown to be the most important fish species in the diet of Magellanic penguins (Scolaro et al. 1999), we selected anchovy as the most representative fish species to estimate the relative contribution of fish and squid to the diet. Using the 2-source isotopic mixing model (see 'Materials and methods'), and using a mean $\delta^{15} \mathrm{~N}$ value of $16.9 \%$ for anchovy and $13.6 \%$ for squid, we determined that anchovy was the dominant component in the diet of chicks (Table 2). This result is in agreement with the previous findings of differences in $\delta^{15} \mathrm{~N}$ among age classes, and confirms that adults consumed a lower proportion of anchovy than chicks, but higher than yearlings (as adults showed higher and lower levels of $\delta^{15} \mathrm{~N}$ than yearlings and chicks, respectively; Fig. 1, Table 2).

Finally, we determined if the diet of chicks (as indicated by their $\delta^{15} \mathrm{~N}$ values) influenced their body condition. Body condition of chicks was positively correlated with their blood $\delta^{15} \mathrm{~N}$ values $(\mathrm{R}=0.42, \mathrm{n}=58, \mathrm{p}<0.001$; Fig. 2$)$. This result indicates that adults that fed their offspring with a higher proportion of anchovy raised chicks of higher quality.

\section{DISCUSSION}

Analyses of stable isotopes in blood of Magellanic penguins revealed a range of individual variation of $2.2 \%$ (17.8 to $20.0 \%$ o) for $\delta^{15} \mathrm{~N}$ and $3.3 \%$ $\left(-14.8\right.$ to $-18.1 \%$ ) for $\delta^{13} \mathrm{C}$ values. Even with this narrow range, relevant dietary differences existed within the population, among individuals from different age and sex classes. Such individual dietary differences have typically not been addressed in most conventional studies of diet in birds. This lack of information is due primarily to the fact that stomach content examination usually results in estimates of simple percent occurrence or percent biomass of prey for whole population samples.

Using isotopic mixing models, and assuming that anchovy and squid dominated the diet (see 'Materials and methods' and 'Results'), estimates of the contribution of anchovy to the diet of Magellanic penguin var-

Table 2. Mean $( \pm \mathrm{SD})$ and range across each category of stable nitrogen and carbon isotope ratios and estimated contribution of anchovy to the diet of Magellanic penguin. Mean anchovy contribution is based on a 2-source mixing model assuming only squid and anchovy dietary alternatives and a $\delta^{15} \mathrm{~N}$ trophic enrichment factor between diet and penguin blood of $3 \%$

\begin{tabular}{|c|c|c|c|c|c|c|c|}
\hline Age/Sex & $\mathrm{n}$ & $\delta^{15} \mathrm{~N}(\% \circ)$ & Range (\%o) & $\delta^{13} \mathrm{C}(\%$ o) & Range (\%o) & $\begin{array}{l}\text { Mean contribution } \\
\text { of anchovy }(\%)\end{array}$ & Range (\%) \\
\hline Chicks & 98 & $19.1 \pm 0.3$ & $18.0-19.9$ & $-16.6 \pm 0.6$ & -18.1 to -15.4 & 76 & $42-100$ \\
\hline Yearlings & 15 & $18.2 \pm 0.3$ & $17.8-18.6$ & $-16.3 \pm 0.3$ & -17.4 to -16.0 & 49 & $36-61$ \\
\hline Adult males & 58 & $18.9 \pm 0.4$ & $18.0-20.0$ & $-16.2 \pm 0.6$ & -17.3 to -14.8 & 69 & $42-100$ \\
\hline Adult females & 62 & $18.8 \pm 0.4$ & $18.0-19.8$ & $-16.5 \pm 0.5$ & -17.5 to -15.6 & 67 & $42-97$ \\
\hline
\end{tabular}




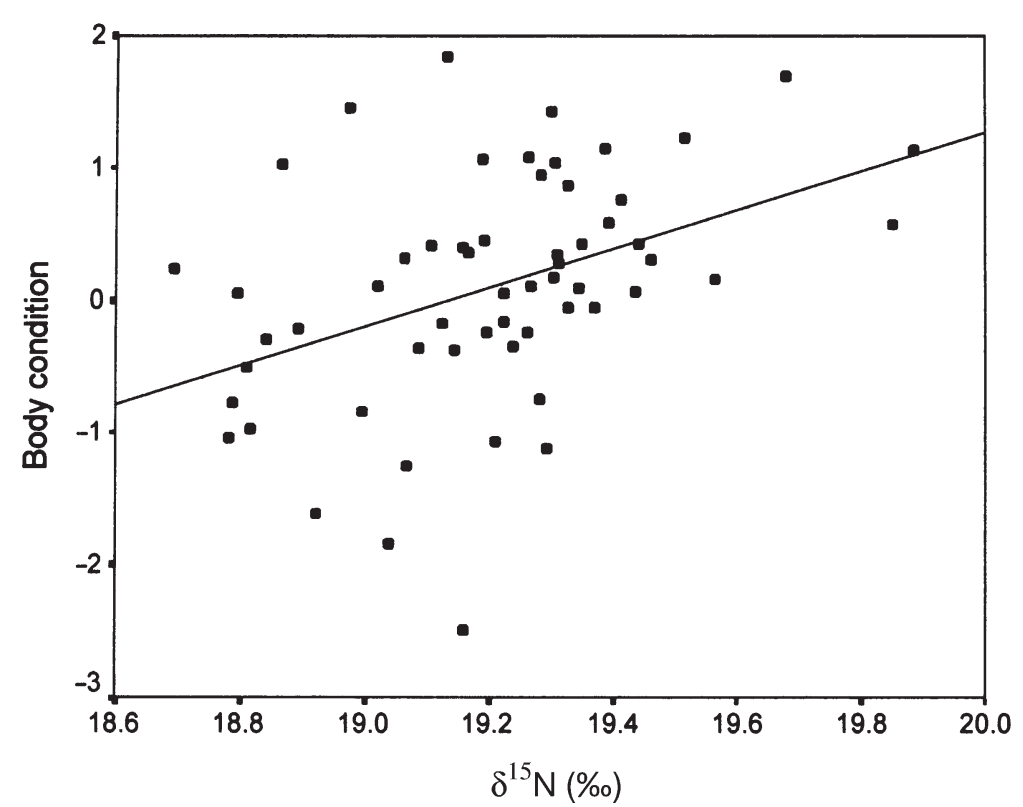

Fig. 2. Results of linear regression analyses between body condition of chicks and their stable nitrogen isotope values

ied from 46 to $76 \%$ depending on age and sex of individuals (Table 2). Although such estimates have not been made previously for this species, our results are in overall agreement with previous studies that concluded that anchovy is the main prey of this species through the breeding cycle (Scolaro \& Badano 1986, Frere et al. 1996, Gandini et al. 1999). Intercolonial differences in diet composition for Magellanic penguin have been previously studied over the species' latitudinal range in Argentina (Frere et al. 1996, Scolaro et al. 1999). Although it was not the main objective of this study, we found that intercolonial differences in stable isotope values exist even among colonies separated less than $100 \mathrm{~km}$. Frere et al. (1996) argued that variability in dietary composition of this species in different locations may be related to geographical differences in the availability of different prey species. The overall distribution of anchovy is larger than the area we have studied and it encompasses waters near all sampled colonies (Ciechomysky \& Sanchez 1988). Therefore, we suggest that in addition to prey distribution, other active mechanisms driving prey selection could exist such as intra- or interspecific competition determined by colony size and distribution (Tella et al. 2001, Forero et al. in press). These factors could determine different degrees of prey depletion and in the same way cause differences among colonies in the diet of this species. However, we have not established whether or not stable-isotope signatures of prey themselves differ geographically on a scale relevant to the foraging areas among the studied colonies (e.g. Schell et al. 1998, Kline 1999).
In addition to the variability in isotope signatures observed between colonies, there were important differences between the sexes and age classes. To our knowledge, few studies have explored sex differences in the diet of Magellanic and other penguin species (see review in Croxall \& Lishman 1987 and Clarke et al. 1998). In this study we report significant differences in $\delta^{15} \mathrm{~N}$ and $\delta^{13} \mathrm{C}$ values in adult males and females within colonies. Males showed higher levels of both isotope signatures (Fig. 1, Table 2), which indicate that they likely took significantly more anchovies and foraged more inshore than adult females. Segregation in food habits (prey size or type) or foraging areas between sexes have been reported for other marine birds including penguins (Volkman et al. 1980, Hobson 1993, Koffijberg \& van Eerden 1995, Kato et al. 1996, 2000, Clarke et al. 1998, González-Solís et al. 2000). Volkman et al. (1980) studying the diet of 3 Pygoscelis species breeding sympatrically on the Antarctic Peninsula found an important sex segregation in the diet of the most dimorphic species, the Gentoo penguin Pygoscelis papua (Agnew \& Kerry 1995), with males consuming significantly more fish than females. The Magellanic penguin is a dimorphic species with males being larger than females (see review in Agnew \& Kerry 1995, Forero et al. 2001, M.B. et al. unpubl. data). The larger bills of males may allow them to capture a higher proportion of fish than females. Frequently, sexual size dimorphism and the subsequent reduction of intersexual competition for food have been proposed as the main causes driving differences in diet between sexes (e.g. Selander 1972, González-Solís et al. 2000, Kato et al. 2000). Alternatively, sex differences in diet could simply be a consequence of sexual dimorphism driven by sexual selection (Hedrick \& Temeles 1989). Information on sex differences in foraging effort and/or feeding frequencies are lacking for Magellanic penguin; however, a differential role of the sexes in the chick attendance and reproduction could also explain the differences in the diet and foraging areas that we reported here (Clarke et al. 1998, Clarke 2001).

Another important source of variation in the diet of the Magellanic penguin was the age of individuals. The isotopic model showed that adults fed their young a higher proportion of anchovy than they consumed themselves. In addition, yearlings showed the lowest $\delta^{15} \mathrm{~N}$ values, indicating that they consumed a lower proportion of anchovy than chicks and adults (Fig. 1, Table 2). Such differences had not been noted before for any species of penguins. The selection of different prey types by adults for feeding their chicks and themselves has been inferred in isotope studies of other 
seabirds (Hobson 1993, Schmutz \& Hobson 1998, Hodum \& Hobson 2000). As with our study, these authors assumed that isotopic fractionation between diet and bird tissue does not change with age (Minagawa \& Wada 1984, Rau et al. 1991, Hobson \& Welch 1995). Other evidence supporting our conclusions that isotopic differences among age classes represent real dietary differences was provided by a recent study by Bearhop et al. (2000), who determined that isotopic differences in blood between adults and chicks of Great Skua Catharacta skua were related to differential concentrations of blood uric acid. Both uric acid and urea are waste products of protein catabolism that are typically depleted in ${ }^{15} \mathrm{~N}$ relative to body proteins (Peterson \& Fry 1987). Thus, in chicks, where catabolism activity is higher than in adults, and uric acid or urea concentration in blood should also be higher than in adults, we would expect lower $\delta^{15} \mathrm{~N}$ values in chick blood relative to blood of adults. In this sense, our findings that chick blood was enriched in ${ }^{15} \mathrm{~N}$ compared with adult blood are conservative, and suggest a real dietary difference between these age groups.

These age-related differences cannot be explained in a context of high availability and regular distribution of the preferred prey (anchovy). Rather, we suggest that breeding constraints should determine the observed differences among age classes. On the one hand, Magellanic penguins, as other seabirds (Bradstreet \& Brown 1985, Pedrocchi et al. 1996, Schmutz \& Hobson 1998, Hodum \& Hobson 2000), can actively feed their young with the most profitable prey, taking for themselves those items with lower food value (Emlen 1966, Stephens \& Krebs 1986). This should be determined proximally by the high energetic requirements of growing chicks (Moreno \& Sanz 1996). On the other hand, differential nutritional quality requirements of chicks may influence prey segregation between parents and offspring. Diet quality refers to several separately operating factors such as digestion time and nutritive value (Massias \& Becker 1990, Hilton et al. 1998). Firstly, it is known that retention times of digesta of fish are typically shorter than those of squid. Wilson et al. (1985) showed that African penguins Spheniscus dermescus digested squids Loligo reynaudi only half as fast as anchovy Engraulis capensis. Faster digestibility of anchovy could be a positive factor promoting adults to feed their chicks this prey type. Secondly, nutritive value, which varies between and within prey species (Hislop et al. 1991, Golet et al. 2000), may influence the observed patterns. Fishes tend to have a higher caloric value and higher lipid and calcium content than squids (Clarke \& Prince 1980, Cherel \& Ridoux 1992). Both the nature of the prey species and their fat and caloric contents have been identified as factors influencing growth rates of the chicks of Jackass Spheniscus dermescus and yellow-eyed penguins Megadyptes antipodes (Heath \& Randall 1985, van Heezik \& Davis 1990). Anchovy is a high-lipid prey compared to squid (Heath \& Randall 1985). Although data on growth rates in relation to diet type are not available for Magellanic penguin, our results indicate that chicks that have been fed with a higher proportion of anchovy (i.e. higher $\delta^{15} \mathrm{~N}$ value) have better body condition (Fig. 2). This, in turn, could result in a higher probability of survival of these individuals, as has been observed in other species of birds (see review in Magrath 1991).

Finally, it is interesting to note that yearling penguins consumed a lesser proportion of anchovy than adult breeding birds. This apparently contradicts the expected pattern: individuals without breeding constraints should exploit the most valued prey. Our result can be satisfactorily explained, however, if anchovy availability is low compared to alternative prey. Thus, yearlings would exploit alternative prey (squid), whereas adults, forced to feed growing chicks, concentrate their foraging effort on anchovies.

Higher $\delta^{13} \mathrm{C}$ values of adults compared with chicks during the chick-rearing period is consistent with the hypothesis that during the chick-rearing phase, adults feed themselves in inshore waters and make longer foraging trips over more pelagic waters to obtain food for their chicks. The duration of foraging trips in Magellanic penguins during the chick-rearing phase is about $24 \mathrm{~h}$, prey gathering taking place $30 \mathrm{~km}$ from the colony (Wilson et al. 1995). After a foraging trip a nest relief between the male and female occurs. As with other penguin species, adult Magellanic penguins tend to partially digest food and transport it as a mass in the proventriculus (Croxall 1987). Therefore, it would appear that the only way to segregate food between parents and their offspring would be to separate food intake in time.

Using the isotopic approach, we have described intraspecific patterns of partitioning of food resources in Magellanic penguins. Although our trophic model is based on assumptions and the sex- and age-related differences found can be considered relative rather than absolute, our results clearly show that breeding adults actively feed their young with high-quality prey, different from those consumed by themselves. This supports a fundamental tenet of optimal foraging theory (Stephens \& Krebs 1986). Our results strongly indicate that this behavior could increase some of the individual potential fitness components (offspring survival) by influencing offspring quality. Such findings highlight the importance of identifying diet requirements of different sex and age classes in the population in order to make predictions about how changes in food availability may affect different demographic parameters. 
Finally, intraspecific variability in prey selection, which could influence interspecific diet overlap and subsequently ecological relationships, should be considered in broader ecological approaches to the study of seabird communities.

Acknowledgements. We thank the Fundación Patagonia Natural, Juan Manuel Grande and Olga Ceballos, and the staff of Natural Reserves on the Patagonian coast for their help during field work and with logistic support. J. L. Tella helped in the field work and made many constructive comments on the manuscript. We also thank the staff of the CNF of Argentina for faciliting blood exportation permits. Blood samples from Isla Vernaci Norte 1 were taken by J. Moreno and J. Potti. D. Harris performed the stable-isotope analyses in the Laboratory of Soil Science, University of California at Davis. P. Healy assisted with sample preparation at the Prairie and Northern Wildlife Research Center in Saskatoon, Canada. Financial support was partially provided by the Junta de Andalucía. G.B. and M.G.F. were supported by post-doctoral grants from the Ministerio de Educación y Ciencia (MEC) of Spain, and M.B. by a post-doctoral grant from the Consejo Nacional de Investigación Científica y Técnica (CONICET) of Argentina. A Natural Sciences and Engineering Research Council of Canada grant to G.R.B., an operating grant from the Canadian Wildlife Service to K.A.H., and the Obra Social Caja de Granada provided additional funding.

\section{LITERATURE CITED}

Agnew DJ, Kerry KR (1995) Sexual dimorphism in penguins. In: Dann P, Norman I, Reilly P (eds) The penguins. Surrey Beatty \& Sons, Sydney, p 299-318

Ainley DG (1980) Seabirds as marine organisms: a review. Calif Coop Ocean Fish Invest Rep 21:48-53

Anderson DW, Gress F, Mais KF (1982) Brown pelicans: influence of food supply on reproduction. Oikos 39:23-31

Bearhop S, Teece MA, Waldron S, Furness RW (2000) The influence of lipid and uric acid upon ${ }^{13} \mathrm{C}$ and ${ }^{15} \mathrm{~N}$ values in avian blood: implications for trophic studies. Auk 117: 504-507

Ben-David M, Flynn RW, Schell DM (1997) Annual and seasonal changes in diets of martens: evidence from stable isotope analyses. Oecologia 111:280-291

Bertellotti M, Yorio P (1999) Spatial and temporal patterns in the diet of the kelp gull in Patagonia. Condor 101:790-798

Boersma PD, Stokes DL (1995) Mortality patterns, hatching asynchrony, and size asymmetry in Magellanic penguin (Spheniscus magellanicus) chicks. In: Dann P, Norman Y, Reilly P (eds) Penguin biology. Surrey Beatty \& Sons, Sydney, p 3-35

Boersma PD, Stokes DL, Yorio PM (1990) Reproductive variability and historical change of Magellanic penguins (Spheniscus magellanicus) at Punta Tompo. In: Davis LI, Darby JT (eds) Penguin biology. Academic Press, London, p 15-43

Bradstreet MSW, Brown RGB (1985) Feeding ecology of the Atlantic alcidae. In: Nettleship DN, Birkhead TR (eds) The Atlantic Alcidae Academic Press, London, p 264-318

Cairns DK (1992) Bridging the gap between ornithology and fisheries science: use of seabird data in stock assessment models. Condor 94:811-824

Cherel Y, Ridoux V (1992) Prey species and nutritive value of food fed during summer to King Penguin Aptenodytes patagonica chicks at Possession Island, Crozet Archipielago. Ibis 134:118-127

Ciechomysky JD de, Sanchez RP (1988) Análisis comparativo de las estimaciones de biomasa de la anchoíta (Engraulis anchoita) en el Atlántico Sudoccidental en diferentes años y con distintas metodologías. Publ Com Tec Mix Frente Mar 4:117-131

Clarke A, Prince PA (1980) Chemical composition and calorific value of food fed to Mollymauk chicks Diomedea melanophris and D. Chrysostoma at Bird island, South Georgia. Ibis 122:488-494

Clarke JR (2001) Partitioning of foraging effort in Adélie penguins provisioning chicks at Béchervaise Island, Antarctica. Polar Biol 24:16-20

Clarke JR, Manly B, Kerry K, Gardner H, Franchi E, Corsolini S, Focardi S (1998) Sex differences in Adélie penguin foraging strategies. Polar Biol 20:248-258

Croxall JP (ed) (1987) Seabirds: feeding ecology and the role in marine ecosystems. Cambridge University Press, Cambridge

Croxall JP, Lishman GS (1987) The food and feeding ecology of penguins. In: Croxall JP (ed) Seabirds: feeding ecology and role in marine ecosystems. Cambridge University Press, Cambridge, p 101-134

DeNiro MJ, Epstein S (1978) Influence of diet on the distribution of carbon isotopes in animals. Geochim Cosmochim Acta 42:495-506-351

DeNiro MJ, Epstein S (1981) Influence of diet on the distribution of nitrogen isotopes in animals. Geochim Cosmochim Acta 45:341-351

Deuel HJ (1955) The lipids II: biochemistry, digestion, absorption, transport and storage. Interscience, New York

Duffy DC, Jackson S (1986) Diet studies of seabirds: a review of methods. Colon Waterbirds 9:1-17

Ellegren H (1996) First gene on the avian W chromosome (CHD) provides a tag for universal sexing of non-ratite birds. Proc R Soc Lond B 263:1635-1641

Emlen JM 1966. The role of time and energy in food preference. Am Nat 100:611-617

Forero MG, Tella JL, Donázar JA, Blanco G, Bertellotti M, Ceballo O (2001) Phenotypic assortative mating and within-pair sexual dimorphism and its influence on breeding success and offspring quality in Magellanic penguins. Can J Zool 79:1414-1422

Forero MG, Tella JL, Hobson KA, Bertellotti M, Blanco G (2002) Conspecific food competition explains variability in colony size: a test using stable isotopes in Magellanic penguins. Ecology (in press)

France RL (1995) Carbon-13 enrichment in benthic compared to planktonic algae: foodweb implications. Mar Ecol Prog Ser 124:307-312

Frere E, Gandini P, Lichtschein V (1996) Variacion latitudinal en la dieta del pinguino de magallanes (Spheniscus magellanicus) en la costa Patagonica, Argentina. Ornitol Neotrop 7:35-41

Gandini P, Frere E, Boersma PD (1996) Status and conservation of Magellanic penguin Spheniscus magellanicus in Patagonia, Argentina. Bird Conservation International 6: 307-316

Golet GH, Kuletz KJ, Roby DD, Irons DB (2000) Adult prey choice affects chick growth and reproductive success in pigeon guillemots. Auk 117:82-91

González-Solís J, Oro D, Pedrocchi V, Jover L, Ruiz X (1999) Bias assoiated with diet samples in Audouin's gulls. Condor 99:773-779

González-Solís J, Croxall P, Wood AG (2000) Sexual dimorphism and sexual segregation in foraging strategies of 
northern giant petrels Macronectes halli during incubation. Oikos 90:390-398

Hatch SA, Sanger GA (1992) Puffins as samplers of juvenile pollock and other forage fish in the Gulf of Alaska. Mar Ecol Prog Ser 80:1-14

Heath RGM, Randall RM (1985) Growth of Jackass penguin chicks (Spheniscus dermescus) hand reared on different diets. J Zool Lond.205:91-105

Hedrick AV, Temeles EJ (1989) The evolution of sexual dimorphism in animals: hypotheses and test. Trends Ecol Evol 4:136-138

Hilton GM, Houston DC, Furness RW (1998) Which components of diet quality affect retention time of digesta in seabirds? Funct Ecol 12:929-939

Hislop JR, Harris MP, Smith, JGM (1991) Variation in the calorific value and total energy content of the lesser sandeel (Ammodytes marinus) and other fish preyed on by seabirds. J Zool Lond 224:501-517

Hobson KA (1993) Trophic relationships among high Arctic seabirds: insights from tissue-dependent stable-isotope models. Mar Ecol Prog Ser 95:7-18

Hobson KA, Clark RG (1992) Assessing avian diets using stable isotopes II: factors influencing diet-tissue fractionation. The Condor 94:189-197

Hobson KA, Clark RG (1993) Turnover of 13C in cellular and plasma fractions of blood: implications for nondestructive sampling in avian dietary studies. Auk 110:638-641

Hobson KA, Welch HE (1992) Determination of trophic relationships within a high Arctic marine food web using $\delta^{13} \mathrm{C}$ and $\delta^{15} \mathrm{~N}$ analysis. Mar Ecol Prog Ser 84:9-18

Hobson KA, Welch HE (1995) Cannibalism and trophic structure in a high Arctic lake: insights from stable-isotope analysis. Can J Fish Aquat Sci 52:1195-1201

Hobson KA, Piatt JF, Pitocchelli J (1994) Using stable isotopes to determine seabird trophic relationships. J Anim Ecol 63: 786-798

Hobson KA, Ambrose WG, Renauld PE (1995) Sources of primary production, benthic-pelagic coupling, and trophic relationships within the Northeast Water Polynya: insights from $\delta^{13} \mathrm{C}$ and $\delta^{15} \mathrm{~N}$ analysis. Mar Ecol Prog Ser 128:1-10

Hobson KA, Gibbs HL, Gloutney ML (1997) Preservation of blood and tissue samples for stable-carbon and stablenitrogen isotope analysis. Can J Zool 75:1720-1723

Hodum PJ, Hobson KA (2000) Trophic relationships among Antarctic fulmarine petrels: insights into dietary overlap and chick provisioning strategies inferred from stableisotope $\left(\delta^{15} \mathrm{~N}\right.$ and $\left.\delta^{13} \mathrm{C}\right)$ analyses. Mar Ecol Prog Ser 198: $273-281$

Jarman WM, Hobson KA, Sydeman WJ, Bacon CE, McLaren EB (1996) Influence of trophic position and feeding location on contaminant levels in the Gulf of the Farallones food web revealed by stable isotope analysis. Environ Sci Technol 30:654-660

Jovani R, Tella JL, Forero MG, Bertellotti M, Blanco G, Ceballos O, Donázar JA (2001) Absence of blood parasites in the Patagonian seabird community: is it related to the marine environment? Waterbirds 24:430-433

Kato A, Nishiumi I, Naito Y (1996) Sexual difference in diet of King Cormorants at Maquarie Island. Polar Biol 16:75-77

Kato A, Watanuki Y, Nishiumi I, Kuroki M, Shaughnessy P, Naito Y (2000) Variation in foraging and parental behaviour of king cormorants. Auk 117:718-730

Kline TC (1999) Temporal and spatial variability of ${ }^{13} \mathrm{C} /{ }^{12} \mathrm{C}$ and ${ }^{15} \mathrm{~N} /{ }^{14} \mathrm{~N}$ in pelagic biota of Prince William Sound, Alaska. Can J Fish Aquat Sci 56:94-117

Koffijberg K, van Eerden MR (1995) Sexual dimorphism in the cormorant Phalacrocorax carbo sinensis: possible implications for differences in structural size. Ardea 83: $37-46$

MacArthur RH, Pianka ER (1966) On optimal use of a patchy environment. Am Nat 100:603-609

Magrath RD (1991) Nestling weight and juvenile survival in the black bird, Turdus merula. J Anim Ecol 60:335-351

Massias A, Becker PH (1990) Nutritive value of food and growth in Common tern Sterna hirundo chicks. O Scand 21:187-194

Michener RH, Schell DM (1994) Stable isotope ratios as tracers in marine and aquatic food webs. In: Lajtha K, Michener RH (eds) Stable isotopes in ecology and environmental science. Blackwell Scientific Publications, Oxford, p 138-157

Minagawa M, Wada E (1984) Stepwise enrichment of ${ }^{15} \mathrm{~N}$ along food chains: further evidence and the relation between $\delta^{15} \mathrm{~N}$ and animal age. Geochim Cosmochim Acta 48:1135-1140

Monaghan P, Uttley JD, Burns MD, Thaine D, Blackwood J (1989) The relationship between food supply, reproductive effort and breeding success in arctic terns Sterna paradisaea. J Animl Ecol 58:261-274

Montevecchi WA (1993) Birds as indicators of change in marine prey stocks. In: Furness RW, Greenwood JJD (eds) Birds as monitors of environmental change. Chapman \& Hall, London, p 217-266

Montevecchi WA, Myers RA (1995) Prey harvests of seabirds reflect pelagic fish and squid abundance on multiple spatial and temporal scales. Mar Ecol Prog Ser 117:1-9

Moreno J, Sanz JJ (1996) Field metabolic rates of breeding Chinstrap penguins (Pygoscelis antarctica) in the South Shetlands. Physiol Zool 69:586-598

Pedrocchi V, Oro D, González-Solís J (1996) Differences between diet of adult and chick Audouin's gulls Larus audouinii at the Chafarinas Islands, SW Mediterranean. O Fenica 73:124-130

Peterson BJ, Fry B (1987) Stable isotopes in ecosystem studies. Annu Rev Ecol Syst 18:293-320

Phillips DL (2001) Mixing models in analyses of diet using multiple stable isotopes: a critique. Oecologia 127:166-170

Phillips DL, Koch PL (2002) Incorporating concentration dependence in stable isotope mixing models. Oecologia 130:114-125

Pierotti R, Annett CA (1991) Diet choice in the Herring Gull: constrains imposed by reproductive and ecological factors. Ecology 72:319-328

Pierotti R, Annett CA (1995) Diet and reproductive performance in seabirds. BioScience 40:568-574

Rau GH, Hopkins TL, Torres JJ $(1991){ }^{15} \mathrm{~N} /{ }^{14} \mathrm{~N}$ and ${ }^{13} \mathrm{C} /{ }^{12} \mathrm{C}$ in Weddell Sea invertebrates: implications for feeding diversity. Mar Ecol Prog Ser 77:1-6

Schell DM, Barnett BA, Vinette KA (1998) Carbon and nitrogen isotope ratios in zooplankton of the Bering, Chukchi and Beaufort seas. Mar Ecol Prog Ser 162:11-23

Schmutz JA, Hobson KA (1998) Geographic, temporal, and age-specific variation in diets of Glaucous gulls in western Alaska. Condor 100:119-130

Scolaro JA (1984) Timing of nest relief during incubation and guard stage period of chicks in Magellanic penguins (Spheniscus magellanicus). Hist Nat 4:281-284

Scolaro JA, Badano LA (1986) Diet of the Magellanic penguin Spheniscus magellanicus during the chick-rearing period at Punta Clara, Argentina. Cormorant 13:91-97

Scolaro JA, Wilson RP, Laurenti S, Kierspel M, Gallelli H, Upto JA (1999) Feeding preferences of the Magellanic penguin over its breeding range in Argentina. Waterbirds 22:104-110 
Selander RK (1972) Sexual selection and dimorphism in birds. In: Champbell B (ed) Sexual selection and the descent of Man. Heinemann, Chicago, p 180-230

Stephens DW, Krebs JR (1986) Foraging theory. Princeton University Press, Princeton, NJ

Stokes DL, Boersma PD (1998) Nest site characteristics and reproductive success in Magellanic penguins (Spheniscus magellanicus). Auk 115:34-49

Sydeman WJ, Hobson KA, Pyle P, McLaren E (1997) Trophic relationships among seabirds in central California: combined stable isotope and conventional dietary approach. Condor 99:327-336

Tella JL, Forero MG, Bertelloti M, Donázar JA, Blanco G, Ceballos O (2001) Offspring body condition and immunocompetence are negatively affected by high breeding densities in a colonial seabird: a multi-scale approach. Proc R Soc Lond B 268:1455-1461

Thompson RD, Lilliendahl K, Solmundsson J, Furness RW, Waldron S, Phillips RA (1999) Trophic relationships among six species of Icelandic seabirds as determined through stable isotope analysis. Condor 101:898-903

Tieszen LL, Boutton TW, Tesdahl KG, Slade NH (1983) Fractionation and turnover of stable carbon isotopes in animal

Editorial responsibility: Charles Peterson (Contributing Editor), Morehead City, North Carolina, USA tissues: implications for ${ }^{13} \mathrm{C}$ analysis of diet. Oecologia 57: $32-37$

van Heezik Y, Davis L (1990) Effects of food variability on growth rates, fledging sizes and reproductive success in the yellow-eyed penguin Megadyptes antipodes. Ibis 132: 354-365

Velando, A, Freire J (1999) Intercolony and seasonal differences in the breeding diet of European shags on the Galician coast (NW Spain). Mar Ecol Prog Ser 188:225-236

Volkman NJ, Presler P, Trivelpiece WZ (1980) Diets of pygoscelid penguins at King George Island, Antarctica. Condor 82:373-378

Wilson RP, La Cock GD, Wilson MP, Mollagee F (1985) Differential digestion of fish and squid in the Jackass penguin Spheniscus demersus. Ornis Scandinavica 16: 77-79

Wilson RP, Scolaro JA, Peters G, Laurenti S, Kierspel M, Gallelli H, Upton J (1995) Foraging areas of Magellanic penguins Spheniscus magellanicus breeding at San Lorenzo, Argentina, during the incubation period. Mar Ecol Prog Ser 129:1-6

Williams TD (1995) The penguins. Oxford University Press Oxford

Submitted: November 17, 2000; Accepted: December 19, 2001 Proofs received from author(s): April 27, 2002 